\title{
Skrivediskurser i norskfaget - en analyse av hvordan norsklærere gir skriveoppgaver på åttende trinn
}

\author{
Marte Blikstad-Balas* \\ Institutt for lererutdanning og skoleforskning, Det utdanningsvitenskapelige fakultet, \\ Universitetet $i$ Oslo
}

\section{Sammendrag}

Norskfaget har et særskilt ansvar for skriveopplæring, og skriveopplæring kan foregå på mange måter. Denne artikkelen tar utgangspunkt i 178 norsktimer fra åttende trinn som den pågående LISA-studien har filmet i 46 ulike klasserom. Jeg har identifisert alle timene der elevene får en tydelig skriveoppgave (n=33), og vurderer hvilke av Roz Ivaničs (2004) seks skrivediskurser som er tydelige i lærernes muntlige skriveordre. Funnene viser at det foregår allsidig skrive-opplæring der flere diskurser er tydelige, men at det klart vanligste er at lærerne ytrer seg innenfor en sjangerdiskurs og en prosessdiskurs. Så å si alle skriveoppgavene elevene gjør har tydelige forventninger til sjanger. Analysene viser også at formål med skriving ofte kobles til sjanger generelt, ikke til spesifikke skriveoppgaver. Ingen av skriveordrene alene kan kategoriseres innenfor en sosial praksis-diskurs eller en sosiopolitisk diskurs.

\section{Nøkkelord: Skriveopplering; skrivediskurser; videostudier; ungdomstrinnet; norskfaget}

\begin{abstract}
The language arts subject has a particular responsibility when it comes to developing students as writers. In this article, I draw on 178 Norwegian language arts lessons from the ongoing LISAstudy. I have identified all the lessons where students have a clearly framed opportunity for sustained writing ( 33 lessons), and I have analyzed the discourses framing writing with the six writing discourses described by Roz Ivanič (2004). The findings suggest that several discourses of writing are prominent, but that the most common is that teachers frame writing within a genre discourse and a process discourse. The study also shows that the purposes of writing are often linked to genres, not to particular writing tasks, and that none of the 33 writing tasks can be categorized within a social practice discourse or a sociopolitical discourse of writing.
\end{abstract}

Keywords: Writing instruction; writing discourse; video studies; Norwegian language arts Received: September, 2017; Accepted: January, 2018; Published: May, 2018

\footnotetext{
^Correspondence to: Marte Blikstad-Balas, Email: marte.blikstad-balas@ils.uio.no 
En av skolens viktigste oppgaver er å gjøre elevene skriftkyndige, slik at de kan delta i dagens tekstliggjorte samfunn. Skriving inngår i alle fag og er definert som en giennomgående og tverrfaglig kompetanse, som norskfaget har et særskilt ansvar for. I gjeldende beskrivelser av norskfaget finner vi ulike og delvis konkurrerende forestillinger om skriving. For det første har vi en ferdighetsforestilling om skriving, i det skriving omtales som en grunnleggende ferdighet i Kunnskapsløftet. For det andre opptrer begreper som sjanger og teksttyper om hverandre i både læreplan og eksamensoppgaver (Blikstad-Balas og Hertzberg, 2015). Videre fremhever Skrivehjulet (og Skrivesenteret) formålsrettet skriving - der et avgiørende premiss er at formålet med skrivingen skal være eksplisitt for eleven (Berge, Evensen og Thygesen, 2016). Flere har problematisert den noe tvetydige begrepsbruken knyttet til det å skrive som enhver norsklærer må forholde seg til - og stilt spørsmål om hvordan disse ulike fore stillingene om skriving utspiller seg i praksis (Breivega og Johansen, 2016; Blikstad-Balas og Hertzberg, 2015).

I denne artikkelen undersøker jeg hva slags forståelser av skriving norsklærere gir uttrykk for når de gir elevene konkrete skriveoppgaver. Et innledende premiss er at hvordan lærere snakker om skriving vil ha betydning for hvordan elevene oppfatter det å skrive, all den tid diskurser alltid påvirker det de betegner. Eller, som Kevin C. Dunn og Iver B. Neumann (2016, s. 2) skriver: «Language does not explain the world as much as it produces it». Ulike lærere vil tilnærme seg skriving og skriveopplæringer på ulike måter. Det vil også ofte være forskjell på hva en skriveoppgave er på papiret eller på tavla, og hva den blir når læreren snakker om den samme oppgaven (Bakke og Skovholt, 2015). Dette er fordi «måten læreren introduserer skriveoppgaven på gjennom helklassesamtalen, kan ha avgiørende betydning for hvordan eleven tolker og løser den» (Bakke og Skovholt, 2015, s. 139).

Med utgangspunkt i 178 norsktimer som har blitt filmet på 8. trinn fra det omfattende LISA-materialet (Klette, Blikstad-Balas og Roe, 2017), studerer jeg hvordan konkrete skriveordre formidles muntlig i helklassesamtaler og hvilke forståelser av det å skrive som vektlegges på tvers av klasserom. Dette giør jeg gjennom en diskursiv analyse av skriveordre. Begrepet skriveordre brukes blant annet i det norske SKRIV-prosjektet og i det danske prosjektet Faglighed og skriftlighed og betegner instruksjoner lærere gir når de skal få elever til å skrive en konkret tekst. Begrepet signaliserer også den skjeve maktrelasjonen som er typisk for skoleskriving - der en lærer definerer hva elevene skal skrive og gjerne også hvordan (Hobel, 2015; Krogh og Hobel, 2012). I noen tilfeller virker skriveoppgaven som en invitasjon til skriving, men det er sjelden en invitasjon elevene kan takke nei til. Eller som Krogh og Hobel (2012, s. 139) oppsummerer det: «Skriveordrer kan fungere igangsattende og produktivt for elevskrivere, men naturligvis også modsat og i alle grader derimellem».

\section{Teoretisk rammeverk}

Denne studien bygger på en sosiokulturell inngang til skriving, der det å skrive forstås som deltagelse $\mathrm{i}$ sosiale praksiser mediert giennom diskurs. Helt sentral i denne forståelsen er at det å tilegne seg skrivepraksiser skjer gjennom deltakelse og 


\section{Marte Blikstad-Balas}

sosialisering i relevante måter å bruke skriving på - på tvers av kontekster (Alvermann, 2009; Barton, 1991, 2007; Bazerman, 2016; Kwok, Ganding III, Hull og Moje, 2016).

Sosiokulturell skriveforskning har tradisjonelt vært opptatt av at skriving ikke skjer bare på skolen men også i en rekke andre situasjoner (Gee, 2007; Hull og Schultz, 2001; MacGillivray og Curwen, 2007; Maybin, 2007; Yi, 2010). I senere år har skriveforskere etterlyst mer kunnskap om de sosiale praksisene knyttet til skriving også innenfor en skolekontekst (Kiuhara, Graham og Hawken, 2009; Kwok mfl., 2016; Olson, 2008). Det er viktig å undersøke hvordan tekster blir snakket om og produsert innenfor en institusjonalisert læringskontekst, fordi skolen har stor definisjonsmakt knyttet til hva skriving er og bør være Barton, 2007; Blikstad-Balas, 2016; Gee, 2004). Dessuten viser flere omfattende studier at elever trenger hjelp for å utvikle seg som skrivere. I et metareview om skriving viser Steve Graham, Karen R. Harris og Amber B. Chambers (2016) at noe av det mest avgiørende for å utvikle elevenes skrivekompetanse er å gi dem anledning til å skrive innenfor gitte rammer, gjerne kombinert med skrivestrategier og planlegging av skrivingen. Også andre studier fremhever betydningen av å snakke om skriving, å planlegge skriving, samt det å vise frem relevante skrivestrategier (Bazerman, 2016; Kiuhara mfl., 2009; Smagorinsky og Mayer, 2014). Dette er aktiviteter som typisk kan finne sted i en skolekontekst.

En diskursiv tilnærming til språk innebærer at tekster alltid sees på som en del av en sosial kontekst, hvilket er helt i tråd med sosiokulturelle forståelser av skriving. En diskurs kan defineres som "tekst i kontekst» (Hitching, Nilsen og Veum, 2011) og viser til konkrete ytringer i gitte sosiale kontekster, samt til «rammene for hva som er rimelig å mene og tro innenfor et gitt fellesskap» (Bratberg, 2017, s. 34). Det er et stort begrep, og vi skal snevre oss inn til diskurser som handler om skriving. Skrivediskurser kan defineres som «ulike måter å tenke og snakke om skriving på: ulike syn på hva skriving på skolen dreier seg om, og hva god skriveundervisning bør legge vekt på» (Smidt, 2009, s. 312). Det er denne forståelsen av skrivediskurser som ligger til grunn for artikkelen.

Det finnes selvfølgelig en rekke måter å snakke om skriving på, og det kan potensielt finnes en uendelig mengde skrivediskurser i norske klasserom. I mine analyser har jeg likevel valgt å se etter seks spesifikke skrivediskurser. Disse er definert av diskursanalytikeren Roz Ivanič, som lenge har vært opptatt av ulike diskurser assosiert med skriving. Hun har identifisert seks skrivediskurser, der skriving knyttes til enten ferdigheter, kreativitet, prosess, sjanger, sosial praksis eller sosiopolitisk praksis (Ivanič, 2004, oversatt til norsk av Smidt, 2009; Veum, 2015). De ulike diskursene sier ikke bare noe om hva skriving er men også noe om hvordan skriving læres, hvordan skriving kan undervises i og hvilke aspekter av skrivekompetanse som blir vurdert. Diskursene spenner fra den skrevne teksten til mentale prosesser knyttet til det å skrive, samt skrivehendelser og skrivingens sosiokulturelle og politiske kontekster. Disse diskursene er relevante også i en norsk kontekst, og ofte vil vi kunne finne flere av dem samtidig i læreplaner, i lærebøker eller i undervisningen (Smidt, 2009; Veum, 2015).

Når lærere snakker om skriveoppgaver i klasserommet, synliggiør de sitt syn på skriving og sitt skrivedidaktiske ståsted (Bakke og Skovholt, 2015), noe som giør 
lærernes muntlige skriveordre til et godt utgansgpunkt for analyser. I denne studien bruker jeg Ivaničs (2004) seks skrivediskurser som utgangspunkt for å analysere lærernes ytringer knyttet til elevenes skriving. Dette er noe Ivanič (2004, s. 226) selv mener hennes rammeverk er egnet til, og hun nevner nettopp (video-)opptak av undervisning som relevante data for å undersøke skrivediskurser. Hovedgrunnen til at jeg har valgt å kategorisere skriveordrene med utgangspunkt i Ivaničs rammeverk, er at det vil kunne gi ny innsikt om lærernes prioriteringer og syn på skriving i det de ber egne elever om å produsere tekster.

\section{Hva antyder tidligere forskning om norskfagets skrivediskurser?}

Selv om få skriveforskere i Norge har valgt å eksplisitt bruke Ivaničs (2004) kategorier i sine analyser, er det fullt mulig å kjenne igjen diskursene hun beskriver også i norsk skole - og i norsk skriveforskning. I denne forskningsgjennomgangen vil jeg derfor fremheve studier som kan si noe om hvilke syn på skriving og skriveundervisning som har vært og er viktige innenfor norskfaget, med utgangspunkt i Ivaničs seks skrivediskurser.

\section{Ferdighetsdiskursen}

Innenfor en ferdighetsdiskurs blir skriving forstått som en ferdighet det må trenes på, spesielt for å mestre forholdet mellom lyd og tegn, samt syntaktisk oppbygging av tekster. Dersom vi ser bort fra den grunnleggende skriveopplæringen og spesialpedagogisk skriveundervisning, er det nok først og fremst andre skrivediskurser som er fremtredende i dagens norskfag. Læreplanen for Kunnskapsløftets (LK06) innramming av skriving som en grunnleggende ferdighet på tvers av fag kan likevel forstås som en vektlegging av skriving som trenbar ferdighet og dermed tolkes som et uttrykk for ferdighetsdiskurs (Smidt, 2009). Dessverre er det nok slik at begrepet «grunnleggende ferdighet» ikke alltid blir forstått i tråd med Kunnskapsløftets intensjoner. Da denne læreplanen ble innført ble det omtalt som en literacy-reform, fordi planen vektlegger at faglig kunnskap alltid formidles gjennom et språklig og kulturelt fellesskap (Berge, 2005; Skjelbred \& Veum, 2013). Selv om LK06 altså forholder seg til skriving som en overordnet kulturell kompetanse (Blikstad-Balas, 2016), er det ikke alltid slik planen blir lest. Studier av hvordan lærere og skoleledere forholdt seg til LK06 og de grunnleggende ferdighetene antyder at flere oppfatter grunnleggende ferdigheter langt snevrere enn intendert (Hertzberg, 2010; Ottesen og Møller, 2010). Frøydis Hertzberg (2006) har problematisert nettopp kombinasjonen av adjektivet "grunnleggende", som kan forstås som noe elementært eller enkelt, og 《ferdighet», med dets tekniske eller instrumentelle assosiasjoner.

\section{Kreativitetsdiskursen}

En kreativitetsdiskurs vektlegger skriving som et resultat av forfatterens mentale prosesser og kreativitet. Her er det altså et poeng at elevene skal gi uttrykk for noe, snarere enn bare å vise at de behersker for eksempel formelle sider ved språket. Smidt (2009) argumenterer for at dette elevorienterte synet har preget norsk skrivedidaktikk lenge. 
Det har vært tradisjon for at elever skal få skrive om noe de mener noe om, og at de skal få uttrykke seg. Da det ble undersøkt hva norske ungdomsskoleelever skrev på avgangseksamen i norsk gjennom det omfattende KAL-prosjektet (Berge, Evensen, Hertzberg og Vagle, 2005), ble det tydelig at elevene foretrekker nettopp subjektiv og kreativ skriving. Siden den gang har eksamen blitt endret slik at alle elever kan regne med å måtte vise kompetanse også i sakskriving på eksamen. Skjønnlitteratur og sakprosa sidestilles i LK06, og i nyere læreverk er det også «ei dreiing bort frå skriveoppgåver som etterspør ekspressivitet og subjektivitet, til fordel for skriving av funskjonell sakprosa» (Veum, 2015, s. 97).

Selv om saktekster har fått en større rolle i norskfaget, er ikke kreativtetsdiskursen borte. Dagens norskeksamen har en egen teksttype som har fått navnet «kreativ tekst», og noe av intensjonen med denne teksttypen er å fremheve det kreative aspektet ved skriving fremfor mer sjangerformalistiske tendenser (Blikstad-Balas og Hertzberg, 2015).

\section{Prosessdiskursen}

Smidt (2009, s. 314) gjør en tydelig kobling mellom prosessorientert skrivepedagogikk og Ivaničs (2004) prosessdiskurs, der å lære å skrive forstås som «å lære seg mentale prosesser som å planlegge en tekst, få oversikt over hva en vil med den, og hvordan den skal bygges opp». Dette innebærer ofte at skrivingen deles inn i ulike skrivefaser, og at en får innspill og respons fra andre underveis i skrivingen. Tidligere forskning har vist at prosessorientert skriving $\mathrm{i}$ ulike former har spilt en viktig rolle siden den kom for alvor på midten av åttitallet (Hertzberg og Dysthe, 2012; Smidt, 2009).

Også nyere studier viser at forståelsen av skriving som prosess står sterkt. Astrid Roe og Kristin Helstad (2014) har undersøkt hvordan norsklærere forholder seg til prosessorientert skrivepedagogikk. De finner at prosessorientert skriving er integrert i lærernes praksiser, og at lærerne i stor grad rapporterer at de bidrar inn i elevenes skriveprosesser på ulike måter. Ivanič (2004, s. 231) understreker at en prossessdiskurs innebærer «the view that learning to write should include the processes and procedures for composing a text». Dette medfører ofte at lærere tar i bruk ulike støttestrukturer for å hjelpe elevene med tekstkomposisjonen. Slik praktisk tilrettelegging av skriveprosessen ser vi blant annet gjennom skriverammer og setningsstartere, som vi finner i flere av dagens læreverk, ikke minst gjennom alle Skrivesenterets ressurser for lærere ${ }^{1}$. Ann Kristin Øgreid (2016) har undersøkt hvordan skriverammer kan brukes som stillasering (scaffolding) i elevenes skriveprosess. Hun viser hvordan lærernes innramming og dialog med elevene underveis i skrivingen motvirker at skriverammen blir instrumentell og sjangerformalistisk, noe som for øvrig stemmer godt med lærernes opplevelser av skriverammer rapportert i studien til Helstad og Hertzberg (2013).

Det at lærere gir kommentarer og innspill på tekster elevene så skal revidere (Bueie, 2016; Blikstad-Balas, Roe og Klette, 2018; Eriksen, 2017; Igland, 2007), kan også forstås som en anerkjennelse av prosessorientert skriving. Selv om dette i dag

\footnotetext{
${ }^{1}$ http://www.skrivesenteret.no/ressurser/skriving-i-norsk/
} 
er etablert praksis i skriveundervisning som vi kanskje nesten tar for gitt, står den i kontrast til tidligere «stiloppgaver» elevene skulle skrive helt uten innspill underveis, og som så ble bedømt av en norsklærer.

\section{Sjangerdiskursen}

Hvilke muligheter ulike sjangre tilbyr, og hvilke sjangre som egner seg best i ulike sammenhenger, har lenge vært et sentralt tema i norskfaget. I Ivaničs (2004) rammeverk er utgangspunktet for sjangerdiskursen en anerkjennelse av at teksters form avhenger av formålet de skal oppfylle, og at det finnes noen typer tekst som egner seg spesielt godt i noen bestemte situasjoner. Innenfor sjangerdiskursen er det aller viktigste kriteriet for en tekst 'appropriacy', altså at den er egnet til det formålet den er ment å brukes i og oppfyller tekstnormene som forventes innenfor den aktuelle sjangeren (Ivanič, 2004, s. 233). Sjangerskriving - og skriving i ulike sjangre - har for lengst tatt over for den tidligere «skolestilen» (Blikstad-Balas og Hertzberg 2015; Vagle og Evensen, 2005). Det ser vi blant annet i norskfagets mange læreverk, der sjangeropplæring og sjangerkjennetegn har en fremtredende rolle. Selv om det internasjonalt ofte er debatt om rendyrket sjangerpedagogikk, er det viktig å merke seg at sjangertankegangen her i Norge har utviklet seg «i beste samforstand med prosessorientert skriving» (Smidt, 2009 s. 314). I Veums (2015) analyser av skrivediskurser i norskbøker for ungdomstrinnet gjennom 30 år er det økende fokuset på funksjonelle sjangre som kan knyttes til ulike situasjoner, et tydelig funn. Hun finner at de tydeligste sjangrene i læreverket Neon fra 2008 er artikkel, leserinnlegg, brev, fortelling, kåseri og dikt (Veum, 2015, s. 91). Veum (2015) understreker hvordan oppgaver i nyere læreverk som ikke ber om en eksplisitt sjanger, likevel forventer sjangerbevissthet fra eleven når de skriver ting som «velg sjanger selv».

\section{Sosial praksis-diskursen}

Skriving vil, i likhet med lesing, alltid påvirkes av de sosiale kontekstene skriving og lesing skjer innenfor (Barton, 2007; Ivanič, Barton og Hamilton, 2000; Sørvik og Mork, 2015). Sosial praksis-diskursen er assosiert med den teoretiske retningen New Litercy Studies (NLS), der en etnografisk har undersøkt skrivehendelser og skrivepraksiser innenfor en rekke domener. Innenfor dette synet på skriving er det formålet med skrivingen som er avgjørende, da skriving blir forstått som å kunne tilpasse seg formålet og de sosiale rammene i den aktuelle konteksten (Veum, 2015). Dette funksjonelle synet på skriving er tydelig i dagens norskfag. Både Kunnskapsløftet, Rammeverk for grunnleggende ferdigheter og Skrivehjulet (Berge mfl., 2016) legger til grunn at skrivekompetanse handler om å kunne bruke skrift til å ytre seg på en forståelig og hensiktsmessig måte, tilpasset ulike situasjoner og formål (Evensen, 2010).

I sin diakrone analyse av skriveoppgaver fant Veum (2015) at den sosiale praksis-diskursen er tilstede allerede i læreverk fra 70-tallet, men at det i nyere læreverk 
er et videre spekter av oppgaver innenfor denne diskursen. Dette er gjerne oppgaver der elevene skal tenke seg at de er i en bestem situasjon, der de har behov for å skrive noe - for eksempel at de har en deltidsjobb der de høflig og forsiktig skal klage til sjefen på arbeidsforholdene (Veum, 2015, s. 93). Denne tankegangen finner vi igjen også i dagens eksamensoppgaver i norsk, som legger opp til at formålet med skrivingen skal være styrende.

\section{Den sosiopolitiske diskursen}

Som navnet antyder, er det i den sosiopolitiske diskursen en bredere kontekst vi tar utgangpunkt i - den overordnede sosiale eller politiske diskursen. Dette innebærer i praksis å adressere blant annet politikk, maktforhold, ideologi, sosial endring - og en avstandtagen fra vurdering av skriving (Ivanič, 2004, s. 239). En sosiopolitisk skrivediskurs har dermed mye til felles med kritisk literacy - det dreier seg om å møte tekster med en viss motstand og stille spørsmål ved etablerte sannheter som medieres gjennom tekst. Kritisk tenkning er nevnt flere steder i LK06, og i enda større grad i ny overordnet del til læreplanen (KD, 2017). Samtidig er det nok slik at en sosiopolitisk skrivediskurs ikke er spesielt utbredt i praksis. Ivanič (2004, s. 239) forklarer at denne diskursen risikerer å bli avvist som politisk og ideologisk, selv om alle skrivediskurser i følge henne vil være et uttrykk for politiske og ideologiske standpunkt.

\section{Metode}

Datamaterialet i denne studien stammer fra den NFR-finansierte LISA-studien (Klette mfl., 2017), der vi har filmet norskundervisning i en uke (3-4 timer) i 46 åttendeklasser skoleåret 2014/2015. Skolene er spredt geografisk, de gjenspeiler ulik sosioøkonomisk bakgrunn, og det er både små og store skoler med i utvalget. Totalt har vi filmet 178 timer med norskundervisning på åttende trinn, og det er disse timene som er utgangspunktet for min studie. I de 46 ulike klasserommene (som jeg gjennomgående referer til ved nummer fra 1-46) har vi filmet både lærer og elever samtidig med den samme kameraløsningen, og vi har brukt en lærermikrofon og en mikrofon midt i rommet som fanger opp lyd fra klassen. Til sammen gir dette designet god oversikt over hvilke aktiviteter som skjer i undervisningen, samt hva læreren sier både i helklasse og i situasjoner med enkeltelever eller små grupper med elever. Klassemikrofonen fanger også opp elevytringer i helklassesamtaler.

Video har vist seg å være et godt utgangspunkt dersom en ønsker å analysere sosial interaksjon og komplekse tektspraksiser (Bjørkvold, 2015; Kucirkova, Messer, Sheehy og Flewitt, 2013; Blikstad-Balas og Sørvik, 2015; Blikstad-Balas, 2017). Video muliggjør transkripsjon og det å studere samme situasjon gjentatte ganger med litt ulike perspektiver, for eksempel ved å se etter seks ulike skrivediskurser i hver enkelt skriveordre. 
For å analysere hvilke skrivediskurser som er fremtredende i undervisningen, har jeg valgt timer der elevene får skrive sammenhengende i minst syv minutter, der det gis en skriveordre med noen uttalte retningslinjer eller forventninger knyttet til form på elevteksten. Det vesentlige med disse to kriteriene er at de gir et utvalg der timene inneholder elevproduksjon av tekster, og der lærerne snakker om skriving og dermed viser noe av sin skrivedidaktikk. Den viktigste innvendingen mot denne fremgangsmåten er at jeg ikke har analysert alt lærerne sier, men heller har sett systematisk på det de velger å eksplisitt vektlegge i sine skriveordre. Det betyr at mange av lærerne har undervisning som er relevant for skriving (for eksempel snakker flere lærere om sjangertrekk når de leser skjønnlitterære tekster, se Gabrielsen, BlikstadBalas og Tengberg, 2017). Slik undervisning er ikke inkludert i min kategorisering av skriveordrene. For å analysere hva lærerne vektlegger mest når de ber elevene skrive, mener jeg likevel min avgrensning er hensiktsmessig - fordi den muliggiør en systematisk analyse av hva lærerne legger mest vekt på når de selv oppsummerer hva det er elevene skal giøre i sin tekst. En muntlig skriveordre innebærer alltid en prioritering av hva slags skriving læreren ønsker å oppmuntre til.

Av de 178 norsktimene er det 33 timer (inkludert åtte dobbelttimer) der elevene skal produsere tekst i minst syv minutter sammenhengende, og der lærerne også uttaler en skriveordre med forventninger eller retningslinjer de har for dette skrivearbeidet. Disse timene har blitt analysert kvalitativt. Studier av ulike 'oppgaveordre' har blitt stadig vanligere i Norden (Slot, 2017). Skriveordre som analytisk enhet har blitt brukt i flere studier og det innebærer at en ser systematisk på instrukser til skriving (Brok, 2014; Christensen, Elf og Krogh, 2014; Hobel, 2015; Krogh og Hobel, 2012). I min studie er det flere lærere som har skrevet ned en skriveoppgave enten på en PowerPoint eller på tavla, men denne kommenteres alltid muntlig. Jeg ønsker å analysere måtene lærerne snakker om skriving på, og hva de faktisk sier om skriveoppgaven som skal giøres når de gir en muntlig instruks til elevene om å skrive. For å klassifisere lærernes skriveordre, har jeg undersøkt hva lærerne sier når de ber elevene om å begynne skrivingen av en gitt tekst. Jeg har transkribert det læreren sier og i noen tilfeller også innspill fra elever. Så har jeg undersøkt hvilke av de seks synene på skriving som kan identifiseres innenfor de ulike skriveordrene. Her ser jeg etter typiske kjennetegn på de ulike diskursene i tråd med gjennomgangen i teoridelen. For eksempel vil det at en lærer oppfordrer til kreative mentale prosesser og ber elevene bruke sin egen kreativitet i skrivingen, tolkes som et uttrykk for kretativitetsdiskurs.

Ivanič (2004) presiserer at det vanlig at ulike skrivediskurser opptrer sammen, så en og samme skriveordre kan ha trekk fra ulike skrivediskurser. Som vi skal se er det for eksempel vanlig at lærerne sier noe om prosess og forventninger til hvordan gjennomføringen av skrivingen skal skje, samtidig som de sier noe om sjangerkrav og bruk av kreativitet. Jeg har derfor ikke brukt kategoriene som giensidig utelukkende kategorier, snarere har jeg sett etter trekk ved alle de seks skrivediskursene i samtlige skriveordre. Dersom en lærer vektlegger for eksempel skriveprosess, sjangertrekk, formelle ferdigheter og kreativitet i sin skriveordre, vil jeg klassifisere 


\section{Marte Blikstad-Balas}

skriveordren som et utrykk for både prosessdiskurs, sjangerdiskurs, ferdighetsdiskurs og kreativitetsdiskurs.

En annen vesentlig nyansering som Ivanič (2004) selv er opptatt av, er at lærere flest er eklektiske, de vil typisk gi uttrykk for en eller to skrivediskurser av gangen innenfor et gitt tema eller en økt. Dermed vil det være lite trolig at de lærerne som her gir skriveordre som kategoriseres innenfor en gitt diskurs eller to, aldri uttrykker seg innenfor andre diskurser. Samtidig er materialet jeg har analysert omfattende, da det er snakk om totalt 178 norsktimer fra 46 ulike klasserom - og kan gi ny kunnskap om hvilke diskurser som fremstår som mest fremtredende i skriveopplæringen på tvers av de klasserommene jeg har studert.

\section{Analyse}

Tabell 1 oppsummerer hva slags skriving elevene holder på med i de norsktimene som analyseres i denne studien. ${ }^{2}$ Det er skriveordrene fra disse timene som er gienstand for den videre analysen. Det samtlige av disse timene har til felles, er at elevene skriver i mer enn syv minutter, og at læreren har gitt minst en eksplisitt skriveordre der det fremgår noe om hva det er forventet at elevene skal skrive.

Tabell 1. Oversikt over skriveoppgaver

\begin{tabular}{ll}
\hline Skjønnlitterære tekster (15) & Saktekster (18) \\
\hline Fortelling (4) & Debattinnlegg/leserinnlegg (7) \\
Beskrivelse /utvide øyeblikk (7) & Artikkel (3) \\
Novelle (1) & Sammendrag/referat (1) \\
Eventyr (2) & Bokrapport (2) \\
Skrive som en 3-åring tenker (1) & Naturfagrapport (samarbeid med naturfaglærer) 1 \\
& Tekstbinding i saktekst (2) \\
& Egne tanker om musikk (1) \\
& Reportasje (1) \\
\hline
\end{tabular}

Som det fremgår av tabellen, er det mange av oppgavene som er enten fortellende skriving eller debattinnlegg, spesielt hvis vi tar i betraktning at de syv skriveordrene som handler om å beskrive eller utvide øyeblikket inngår i lengere undervisningsforløp om noveller eller fortellinger. Dette er tydeligvis populære sjangre på åttende trinn, noe som også gjenspeiles i læreverkene som var i bruk på de ulike skolene. Vi kan også merke oss at skriveordrene fordeler seg relativt jevnt på både skjønnlitterær skriving og sakskriving. En enkel telling av forekomster av de ulike diskursene (som altså ikke er gjensidig utelukkende), viser at sjangerdiskursen er tydelig i 22 av skriveordrene, prosessdiskursen i 16, kreativitetsdiskursen i syv og

${ }^{2}$ For en fullstendig oversikt over aktiviteter i de ulike timene, se Blikstad-Balas, Roe og Klette (2018), tabell 3. 
ferdighetsdiskursen i fem. Ingen av de 33 skriveordrene er kategorisert som sosial praksis-diskurs eller sosiopolitiske diskurs.

Langt mer interessant enn selve tellingen, er hva som er typisk for lærernes skriveordre innenfor de ulike skrivediskursene. I det følgende vil jeg gi eksempler på de ulike diskursene i Ivaničs (2004) rammeverk og vise hvordan de ulike diskursene manifesterer seg.

\section{Ferdighetsdiskurs}

I alt er det kun fem av de 33 timene som inneholder en tydelig ferdighetsdiskurs, og ingen lærere i denne analysen gir skriveordre som kan plasseres utelukkende innenfor en ferdighetsdirskurs. En ferdighetsdiskurs innebærer at skriving er en ferdighet som krever trening og bevisst opplæring. Analysen viser at få lærere vektlegger rettskriving eller øving i sine skriveordre, og som Smidt (2009, s. 313) også understreker, er ikke ferdighetsdiskursen noe vi ofte finner i rendyrket form i norske klasserom. De tydeligste eksemplene på en ferdighetsdiskurs er i de timene der elevene jobber med å trene på konkrete skrivemåter eller trene på skriving på setningsnivå, for eksempel når de øver på tekstbinding eller trener på å skrive sammendrag. Her er et typisk eksempel på en slik innramming av skriving:

Lærer (skole 37): Nå vil jeg at dere skal giøre oppgaver. Side 104, oppgave to der. Da må dere ha skriveboka igjen. Oppgave to. «Skriv av og bind sammen tekst». Så dere må skrive teksten i skriveboka. I teksten nedenfor er ingen av setningene bundet sammen. Bind dem sammen med «og», «eller», «men», «for» slik du mener det passer. (Læreren leser teksten de skal jobbe med.)

I tillegg er det faktisk to skriveordre som inneholder det motsatte, altså en «antiferdighetsdiskurs", der læreren eksplisitt ber elevene om å $i k k e$ vektlegge formelle sider ved skriving, som rettskriving. En slik oppfordring er hentet fra skole 40, der elevene skriver noveller. Læreren avslutter sin forklaring av oppgaven på følgende måte:

Lærer (skole 40): [...] Dere kan tenke på at dette er jo ikke hovedinnleveringen deres. Hovedinnleveringen er etter påske og da skal dere få tenke på rettskriving $\mathrm{i}$ tillegg, ikke sant? Nå er det først og fremst innholdet som er viktig, og da må dere tenke på det her med skildringer og beskrivelser. Er det noen spørsmål?

Det at ferdighetsdiskursen er lite fremtredende betyr ikke at lærerne ikke vektlegger for eksempel rettskriving i den endelige vurderingen sin, men underveis i skriveprosessen er det lite som tyder på at ferdighetsdiskursen er gjeldende. Flere av timene jeg har analysert, innebærer at elevene skal forholde seg til bestemte skrivemåter og dermed utvikle skriveferdighetene sine i bred forstand - men det er da så å si alltid forankret i en tydelig sjangerdiskurs der målet er å mestre sjangerrelevante uttrykksmåter.

\section{Kreativitetsdiskursen}

Syv av de 33 skriveordrene er innenfor en kreativitetsdiskurs. Selv om noen av disse skriveordrene er knyttet til sjangre (da hovedsakelig novelle og fortelling), er de også rammet inn som relativt korte oppgaver, gjerne knyttet til «å utvide øyeblikket» 
eller «å beskrive» på en levende måte. Da gir lærerne konkrete scenarier elevene skal beskrive. Dette skjer for eksempel på skole 3, i det læreren selv betegner som «en kreativ skriveøvelse» og «skikkelig gøy» i forkant:

Lærer (skole 3): Ok, lukker dere øynene? Nå skal dere lukke øynene og så skal dere høre på hva jeg sier. Dere skal høre og fantasere. Lukk øynene. Dere er litt for sene med å lukke øynene her foran...Tre...To...En. Nå lukker vi øynene alle sammen. Nå sitter du på en stubbe i skogen. Og du ser rundt deg hva som har skjedd. Og du hører kanskje noen lyder. Du kjenner kanskje en spesiell lukt. Du sitter der helt alene for deg selv på stubben i skogen. Så teller jeg til tre, to, en, så åpner du øynene og da skriver du ned hva som har skjedd. Hva hører du? Hva lukter du? Hva er dette for noe? Tre. To. En. Begynn å skrive!

Også læreren på skole 25 bruker eksplisitt begrepet «kreativ skriving» når elevene blir bedt om å skildre hvordan de har det akkurat nå:

Lærer (skole 25): Selv om det er mandagsmorgen... formiddag, så må dere være litt kreative. Kreativ skriving er ett av de nye ordene i læreplanen. Og da skal dere skildre og det er for så vidt en litt interessant oppgave det. For du skal rett og slett, Marianne, skildre hvordan du føler det nå. Hvordan er det å sitte i klasserommet nå? Da må det være helt stille, ikke sant, også må dere se dere rundt. Og det er ofte sånn at man faller i fella og at det bare blir det man kan se. Men har vi flere sanser enn synssansen? Ja? [Elevene foreslår lyder, lukter, tanker] I skildringen din så kan du bruke tankene dine, men vi må passe på at det er sansene som står i fokus [...] Så rett og slett, her er det snakk om å være kreative. Hvor mye tid trenger dere?

Det typiske for kreativitetsdiskursen i dette materialet er - som begge eksemplene viser - at oppgavene er korte, kreative skriveøvelser, og at de forekommer i forbindelse med skjønnlitterære sjangre.

\section{Prosessdiskurs}

Det at skriving anses som en prosess er tydelig når lærerne snakker om skriving. I dette materialet har 16 av 33 timer blitt kodet som timer der skriveordnene er innenfor en prosessdiskurs. Prosessdiskursen kan komme til uttrykk på flere måter. Analysene viser at mange lærere ber elevene lage disposisjoner og planlegge skrivingen sin, legger opp til flere utkast av tekst eller ber elevene revidere egne og andres tekster. Et illustrerende eksempel på prosessdiskursen finner vi på skole 13, der elevene skal skrive fortellinger. Før elevene går i gang med selve skrivingen, er det satt av tid til planlegging og elevene får også en såkalt «innholdsstjerne» for å planlegge det som skal skrives:

Lærer (skole 13): [...] Så målet for denne timen er at dere skal finne ut hva dere skal skrive om og dere skal prøve å få skrevet en innledning før vi går her i dag. Det første vi skal gjøre er at vi skal gjennomgå oppgaven som noen av dere har fått og så skal dere andre få den. Så skal dere fylle ut innholdsstjerna som dere kjenner til. Og så vil jeg at når dere har fylt ut den så skal dere rekke opp hånda også kommer jeg og gir dere en tilbakemelding på om det kommer til å fungere i forhold til oppgaven dere har valgt. Hvis dere da får «kjør på, dette høres kjempebra ut!» så begynner dere å skrive historien. 
Denne skriveordren er tydelig forankret i en prosessorientert skrivedidaktikk. For det første legger læreren opp til at elevene skal planlegge teksten sin. For det andre antydes det at dette er noe elevene er vant til, da «innholdsstjerna» omtales som noe elevene kjenner til fra før. Videre er dette en lærer som skal gi respons på elevenes plan for skrivingen og diskutere det planlagte innholdet før elevene går i gang med skrivingen. Her er det altså både skrivefaser og respons.

Et annet eksempel på prosessdiskursen vektlegger revisjon og forbedring av teksten - i dette tilfellet en tøysete artikkel der elevene skal skrive saklig om noe som ikke finnes:

Lærer (skole 27): [...] Hvis noen er ferdige så kan de godt starte på et utkast til en [artikkel] til, eller korte ned på den de har eller jobbe med fortetning. Og se kanskje også på språket i det de har skrevet, om det har forbedringspotensiale. For om du har skrevet en tekst kun en gang så skal den ikke være god nok. Da er det noe galt. Et førsteutkast, noe du har skrevet en gang, der skal det være muligheter til å endre på noe og se på gjentakelser, overganger. Sjekk hvordan du har skrevet det her. Skal vi si ti minutter? Det holder? Ok. Rekk opp hånda om du lurer på noe.

Mange av skriveordrene i materialet viser hvordan lærerne deler opp skriveprosessen i mindre skriveaktiviteter og gir stillaser for planlegging (i form av skriverammer eller måter å planlegge tekst på). Selv om lærernes muntlige tilbakemeldinger til elevene underveis i skrivingen ikke er en del av denne analysen, er det et klart tegn på prosessorientert skrivepedagogikk at lærerne i så stor grad prioriterer å bruke tid på skriving i timene, der de også gir tilbakemeldinger til elevene underveis.

\section{Sjangerdiskurs}

Der elevene skal skrive sammenhengende tekster, er det så å si alltid tydelig hvilke sjangerforventninger som gjelder. 22 av 33 timer er kodet som timer der skriveordrene kan tolkes som uttrykk for en sjangerdiskurs. Her benevner lærerne en sjanger, og de sier ofte noe om virkemidler, typiske sjangertrekk eller referer tilbake til undervisning om sjanger eller sjangerspesifikke kriterier. Dette skjer blant annet på skole 40, der elevene har tatt med seg hver sin lille gjenstand (for eksempel en minnepenn eller en tube superlim) som de skal gi en rolle i tekstene sine. Tekstene omtales først som fortelling, men i løpet av skriveordren blir det tydelig at læreren vil at elevene skal skrive noveller:

Lærer (skole 40): Du skal lage en fortelling hvor den her gjenstanden er den del av fortellingen. Det trenger ikke være det viktigste i fortellingen, men det skal komme inn der en plass, sant. Så den minnepennen din [henvender seg til en bestemt elev] kan jo være veldig spennende i den fortellingen, for eksempel. Akkurat som superlimet til Bastian kan være. Så dere skal bare prøve å plassere gjenstanden sånn at den får en naturlig plass i fortellingen. Så egentlig har dere et veldig fritt spillerom når dere skal skrive den her. Men jeg har litt lyst til at dere skal prøve å forholde dere mest mulig til novellesjangeren vi har jobbet med i det siste. Så da må dere tenke litt på hvordan dere skal starte. Ofte så starter jo en novelle midt i handlingen, in medias res, rett på. Så det kan jo være en mulighet. Og så må dere tenke på hvordan dere skal få frem den gjenstanden i handlingen. Skal den være et symbol på noe, 


\section{Marte Blikstad-Balas}

eller skal den være et redskap dere skal bruke, eller hovedpersonen skal bruke, i den her fortellingen, sant. Så tenk på det på den måten.

Som jeg har vært inne på før, opptrer sjangerdiskurs og prosessdiskurs ofte sammen. Slik er det også i dette materialet, der 13 skriveordre er innenfor både en prosessdiskurs og en sjangerdiskurs. Følgende skriveordre fra skole 33 er et godt eksempel på dette, der elevene blir bedt om å skrive eventyr, samtidig som skrivingen er planlagt fordelt over flere uker:

Lærer (skole 33): Målet for denne timen og flere timer fremover neste uke, er at dere nå skal greie å produsere et eventyr. Så i dag har jeg ett mål og det er at dere rett og slett skal komme i gang med å skrive et eventyr. Før dere kommer i gang med å skrive dette eventyret så skal dere få lage en disposisjon, det vil si en plan over det eventyret. Og så regner jeg med at dere kommer så smått i gang med å skrive.

Etter denne innledningen snakker læreren om eventyrsjangeren, før hun ber elevene begynne med disposisjon og arbeid med en spesifikk skriveramme tilpasset eventyrstruktur.

På skole 38 skal elevene skrive leserinnlegg. De har snakket om sjangeren, og læreren inkluderer også elevenes innspill om sjanger i skriveordren sin ved å spørre dem om sjangerkjennetegn:

Lærer (skole 38): Dere skal altså skrive nå et leserinnlegg og det skal leveres på it’s learning og det skal være levert før påske, altså neste fredag. Og jeg vil bare ta en liten gjennomgang og oppfrisking av hvordan vi skal bygge opp leserinnlegget så dere har det klart. August, hvordan starter et leserinnlegg?

Lærer (skole 38): Ja, jeg tror vi.... Jeg skal bare si at på it’s learning så legger jeg ut vurderingsskjemaet som jeg kommer til å bruke også. Jeg kommer til å legge vekt på tittelen, strukturen i teksten, at dere har innledning, hoveddel og avslutning og avsnitt. At dere er saklige og at dere bruker ulike typer argument. Signatur... Og jeg kommer selvfølgelig også til å se på språket dere bruker, hvordan det er. Og bruk hverandre nå og bruk meg når dere skal skrive. Hør med naboen om hva den syntes om det dere har skrevet, og del og få tips av hverandre. Og da sier vi klar, ferdig, gå!

I denne ytringen ser vi igjen interdiskursivitet: læreren er opptatt av sjangerspesifikke krav som saklig språk, ulike typer argumenter og at leserinnlegget skal ha en signatur, men også andre skrivediskurser antydes. Selv om denne skriveordren ikke er noe uttrykk for en ren ferdighetsdiskurs, kan ferdigheter sier å være svakt antydet i det læreren nevner at språk skal vurderes. Videre antydes en prosessdiskurs der læreren oppfordrer elvene til å bruke medelever for å få respons på tekstene før fredagens endelige innlevering. Selv om sjangerdiskursen er tydelig dominerende i mange av skriveordrene, forekommer den altså ofte sammen med andre skrivediskurser. Dette skjer imidlertid ikke på en slik måte der det blir vanskelig å si noe om hva slags diskurs som gjelder, snarere er det slik at der sjangerdiskursen opptrer sammen med andre syn på skriving, er den alltid overordnet. Noe som understreker dette, er at på 
tvers av alle timene er det ofte at elevene får ta valg knyttet til tematikk, om de vil gi hverandre respons, få respons fra lærer og så videre - men sjangeren er alltid gitt. Jeg har ikke funnet skriveordre i de 178 norsktimene der elevene fritt får velge sjanger eller formål selv. Dette kan ha flere forklaringer. Det hadde for eksempel vært interessant å undersøke om sjangerfokuset er like sterkt i tiende trinn, der elevene forventes å kunne velge sjanger selv på eksamen.

\section{Sosial praksis-diskursen}

Det har vært økt fokus på hva formålet med skrivingen blant norske skriveforskere (Berge mfl., 2016; Kringstad og Kvithyld, 2013) og dette gjenspeiles også i eksamensformen. I dette materialet er det likevel ingen skriveordre som kan sies å være innenfor en sosial praksis-diskurs. Dette kan ha flere forklaringer. Det er selve skriveordrene som er analyseenheten i denne artikkelen, fordi skriveordre sier noe om hva som vektlegges mest i det elevene blir oppfordret til å skrive. Mangelen på formålstankegang i selve skriveordren betyr imidlertid ikke at sosial praksis-diskurs aldri forekommer i undervisning. Der lærerne snakker om formål med skriving, er det gjerne knyttet til sjanger generelt (ikke en spesifikk skriveoppgave), og så blir sjangeren - og altså ikke formålet - nevnt spesifikt i skriveordren. Et typisk eksempel er at læreren snakker om sjangeren leserinnlegg og om at formålet med leserinnlegg generelt er å overbevise leseren om noe, og så blir elevene på et senere tidspunkt, kanskje en helt annen time, bedt om å skrive leserinnlegg. Skriveordrene har da et sjangerfokus, og langt på vei blir sjangeren et (for-)mål i seg selv. På skole 38, som vi nettopp så et eksempel fra, skriver elevene leserinnlegg. Som vi så, vektla ikke denne skriveordren sosial-praksis, men hovedsakelig sjanger. Selv om sosial-praksis dimensjonen ikke er tydelig i selve skriveordren, er læreren på skole 38 opptatt av formål, men det kommer til uttrykk på andre tidspunkt enn når elevene selv skal skrive. Læreren sier blant annet følgende $i$ en felles gjennomgang lenge før elevene får skriveoppgaven sin:

Lærer (skole 38): [...] Og den som er veldig glad i å bruke humor, Leif [elev], for eksempel, ikke sant, må spare humoren sin til en annen sjanger. Du kan bruke humor, det er ikke det, men det skal være saklig og holde seg til saken. Du blir mer troverdig da, man tror mer på deg da. Også er det sånn at jo mer du begrunner, jo bedre er argumentet. Så ikke bare sleng ut en påstand og en setning, men prøv å komme med flere begrunnelser for da blir liksom argumentet ditt litt tyngre, og en tror mer på det. Og dere har lettere for å påvirke da.

Her er det altså tydelig at sjangeren leserinnlegg knyttes til både det å være troverdig og det å påvirke. Så at sosial praksis-diskurs ikke er tydelig i selve skriveordren som kommer senere, trenger ikke bety at det ikke nevnes $i$ undervisningen for øvrig.

En annen mulig forklaring på at ingen av skriveordrene er innenfor en sosial praksis-diskurs handler om skolekonteksten. Innenfor en sosial praksis-diskurs, omtales skriving som det å kunne tilpasse seg formål og sosiale rammer i ulike kontekster. Samtidig vet både lærere og elever at den sosiale situasjonen de befinner seg i er 
den samme; læreren er mottaker av teksten, ofte skal den vurderes, og uavhengig av hva slags formål som oppgis, vil lærerens bedømming alltid være det reelle formålet.

\section{Sosiopolitisk diskurs}

Ingen av skriveordrene jeg har analysert kan tolkes som uttrykk for en sosiopolitisk skrivediskurs, og i motsetning til sosialpraksis-diskursen er det ikke slik at denne diskursen er åpenbar andre steder i skriveforløpene enn selve skriveordren. I den grad formål overhode nevnes, er det alltid lokale formål (vurdering, vise at en behersker en gitt sjanger, skrive en overbevisende tekst, og så videre), ikke overordnede sosio-politiske formål. Dette er ikke veldig overraskende, da kritisk literacy er noe som stadig etterlyses i skolen både internasjonalt og i Norge. Dessuten er selve skolekonteksten igjen en nærliggende del av forklaringen. Det er nok lite trolig at elever innenfor skolens ramme har reell mulighet til å skrive tekster som påvirker politikk, maktforhold, ideologi, sosial endring, eller at det er rom for skriveoppgaver som tar avstand fra vurdering av skriving - et sentralt trekk ved den sosiopolitiske diskursen (Ivanič, 2004, s. 239).

\section{Diskusjon}

Et kjennetegn ved gode skriveordre er at de gjerne er presise og gir klare føringer på hva som forventes av oppgaven - hvem den skrives til og hvorfor (Bak, Brok og Korsgaard, 2015). I denne studien er det ofte tydelige forventninger i skriveordrene til hvordan det skal skrives. I over halvparten av de 46 klasserommene blir det gitt minst en skriveoppgave der elevene får klare føringer om innhold og eller form, og der de skal skrive i mer enn syv minutter. Det er et positivt funn, og det tyder på at norsklærerne i dette materialet prioriterer å la elevene skrive i norsktimene. Likevel er det flere skrivedidaktiske utfordringer (Hobel og Piekut, 2016) i dette materialet som det er verdt å diskutere videre.

Det tydeligste funnet i denne studien er at sjanger vektlegges så å si hver gang elevene skal skrive en lengere tekst. Også når elevene arbeider med å skrive skildringer eller skrive spennende, kan dette knyttes til sjangre som novelle eller fortelling. Det er mange gode grunner til å vektlegge sjanger og sjangernormer i undervisningen, all den tid det å mestre ulike relevante sjangre er en vesentlig del av det å være skriftkyndig. Det store spørsmålet er jo om det blir for mye fokus på sjanger. Et funn i denne studien som kan tolkes forsiktig i den retning, er at formålet med skrivingen ikke blir eksplisitt uttalt i selve skriveordren, men heller tas opp som et trekk ved sjangeren i forkant. Dette kan føre til en noe overfladisk forståelse av formål - der det settes likhetstegn mellom gitte sjangre og gitte formål. Sjangeren debattinnlegg for eksempel, blir da koblet til formålet «å overbevise», og når elevene så skal skrive selv, får de kun oppgitt sjanger. Dette kan oppfattes som noe sjangerformalistisk, da formål med skriving ikke kan kobles ukritisk og statisk til en gitt sjanger. For å lykkes med formålsrettet skriveundervisning er det viktig at formålet kommer frem i hver 
enkelt skrivesituasjon, ikke bare som et gitt trekk ved sjangeren. En annen utfordring dersom sjangerfokuset blir for sterkt, er at norskfagets tekstkultur ikke vil kunne være i nærheten av å speile samfunnets spenn av tekster. Sjangerkravene i de fleste reelle skrivesituasjoner er nok langt mindre definert eller avgrenset enn innenfor en norskoppgave. En viktig implikasjon av dette er at tekster som utfordrer norskfagets tekstnormer, og som bryter sjangerkrav eller er vanskelig å plassere i en gitt sjanger, trolig vil bli unngått som eksempeltekster for skriving. Disse trekkene er for øvrig helt i tråd med det Ivanič (2004, s. 233-234) fremhever som kritikken av sjangerpedagogikk, at skolen i sin iver etter å tydeliggjøre tekstnormer ender opp med å overforenkle og fremstille tekster innenfor en gitt sjanger som langt likere enn de er.

Analysen viser også at sjangerdiskursen ofte skjer sammen med en prosessdiskurs, uten at dette ser ut til å være noe motsetningsforhold eller konflikt. Det kan være til stor hjelp for elevene å dele skriveprosessen opp i mindre faser, å jobbe systematisk med planlegging og å diskutere skrivingen underveis (Graham mfl., 2016; Torrance, 2016) - noe lærerne i denne studien ofte kombinerer med eksplisitte sjangerkrav. Dette er altså nok en studie som viser at norske lærere legger vekt på hele skriveprosessen og tilrettelegger med forarbeid, disposisjoner, skriverammer og utkast. Det er gjennomgående at når lærerne i denne studien faktisk prioriterer skriving i timen, bruker de mye tid på å legge til rette for god skriving. De prioriterer også selv å gi respons og konkrete innspill til enkeltelever. Dette er det all grunn til å være positiv til.

Et trekk ved den prosessorienterte tilnærmingen til skriving som Deborah Myhill (2017) likevel problematiserer, er at læreren på sett og vis må «spå» eller forutsi hvordan elevenes skriveprosesser blir og etablere en felles prosess hele klassen tar del i. Myhill (2017) har selv forsket på profesjonelle skriveres skriveprosesser og viser hvordan det å planlegge skriving er en svært omfattende affære - og at skriving ikke egentlig kan planlegges som ett felles løp for klassen. Hun hevder at skriveprosessen ofte fremstilles som en lineær prosess, med steg som "plan, draft, revise, edit», noe mange av timene i dette materialet også tyder på. Også Ivanič (2004, s. 231) problematiserer at prosessdiskursen ofte blir redusert til praktiske forhold rundt den antatt kollektive skriveprosessen i klasserommet, fremfor de mentale aspektene ved skriving som prosess. Kan hende ville det vært bra om prosessdirskursen ble utvidet til også å omfatte noe mer fleksibilitet og individuell tilpasning, og åpnet for at elevene for eksempel kunne gå tilbake til tidligere utkast eller planlegge deler av teksten på ny. Det hadde også vært spennende å undersøke i fremtidige studier hvorvidt prosessdiskursen tilpasses ulike sjangre, eller om skriveprosessen planlegges likt uavhengig av om det er et eventyr eller et essay som skal skrives av elevene.

Mangelen på sosial praksis-diskurs og sosiopolitisk diskurs i selve skriveordrene er kanskje ikke så overraskende, og som jeg allerede har vært inne på, er det flere mulige grunner til at disse diskursene mangler i de 33 skriveordrene. Det kan være en stor utfordring å lage gode, tydelige oppgaver der formålet er tydelig kommunisert. Jeg vil ikke argumentere for at lærere alltid skal konstruere alternative, fiktive formål av typen «tenkt deg at du er journalist i og skal skrive en fagartikkel om gruppepress blant 
ungdommer». Samtidig vil jo en lengere tekst skrevet som del av norskopplæringen alltid ha minst en leser - læreren. Kanskje er det rom forskriveordre som er tydeligere på formålet med skrivingen, ikke bare innenfor norskfagets sjangerdiskurser, men også knyttet til samfunnsaktuelle og globale spørsmål. En sosiokulturell forståelse av sjanger kan harmonere godt med en sosiopolitisk inngang til skriving der skriving knyttes til kritisk tilgang og utfordring av konvensjoner. Ved å utvide skriveordrene noe, vil det som allerede er tydelig skriveopplæring kunne imøtekomme de nye overordnede aspektene av læreplanens overordnede del om demokrati og medborgerskap og kritisk tenkning.

\section{Takk}

Jeg vil gjerne takke de anonyme fagfellene for svært konstruktive tilbakemeldinger og mange gode råd. Jeg vil også takke vitenskapelig assistent Maren Liestøl Jahnsen for hjelp med transkripsjoner. Mine kollegaer Astrid Roe og Kari Anne Rødnes fortjener en stor takk for gode innspill på en tidligere versjon av dette manuset - og hele LISA-prosjektet med prosjektleder Kirsti Klette i spissen takkes for gode faglige samtaler og entusiastiske innspill underveis.

\section{Referanser}

Alvermann, D. E. (2009). Sociocultural constructions of adolescence and young people's literacies. I L. Christenbury, R. Bomer \& P. Smagorinsky (Red.), Handbook of adolescent literacy research (s. 14-28). New York \& London: Guilford.

Bak, M. B., Brok, L. S. \& Korsgaard, K. (2015). Skrivedidaktik: en vej til leering. Århus: Forlaget Klim.

Bakke, J. O. \& Skovholt, K. (2015). "Å forestille seg betyr å bruke fantasien til å tenke på noe som ikke fins». Introduksjon av skriveoppgaver på 7.trinn. I H. Otnes (Red.), A invitere elever til skriving. Ulike perspektiver på skriveoppgaver. (s. 139-158). Bergen: Fagbokforlaget.

Barton, D. (1991). The social nature of writing. I R. Ivanic \& D. Barton (Red.), Writing in the Community (s. 1-13). London: Sage.

Barton, D. (2007). Literacy: an introduction to the ecology of written language. Malden, Mass.: Blackwell Pub.

Bazerman, C. (2016). What do sociocultural studies of writing tell us about learning to write? I C. A. MacArthur, S. Graham \& J. Fitzgerald (Red.), Handbook of writing research. 2, 11-25. New York \& London: The Guilford Press.

Berge, K. L. (2005). Skriving som grunnleggende ferdighet og som nasjonal prøve - ideologiog strategier. I A. J. Aasen \& S. Nome (Red.), Det Nye norskfaget 161, 161-189. Bergen: Fagbokforlaget.

Berge, K. L., Evensen, L. S., Hertzberg, F. \& Vagle, W. (2005). Ungdommers skrivekompetanse: Norskeksamen som tekst. Bind 2: Universitetsforlaget.

Berge, K. L., Evensen, L. S. \& Thygesen, R. (2016). The Wheel of Writing: a model of the writing domain for the teaching and assessing of writing as a key competency. The Curriculum fournal, 27(2), 172-189.

Bjørkvold, T. (2015). Fra avskrift til populærvitenskapelig artikkel-mottakerbevissthet som didaktisk grep. Acta Didactica Norge, 9(1), Art. 17, 23 sider.

Blikstad-Balas, M. \& Sørvik, G. O. (2015). Researching literacy in context: using video analysis to explore school literacies. Literacy, 49(3), 140-148.

Blikstad-Balas, M., Roe, A., \& Klette, K., (2018). Opportunities to Write: An Exploration of Student Writing During Language Arts Lessons in Norwegian Lower Secondary Classrooms. Written Communication. 35(2), s. 119-154.

Blikstad-Balas, M. \& Hertzberg, F. (2015). Fra sjangerformalisme til sjangeranarki. Norsklcereren, 39(1), 47-51.

Blikstad-Balas, M. (2016). Literacy i skolen. Oslo: Universitetsforlaget. 


\section{Skrivediskurser $i$ norskfaget}

Blikstad-Balas, M. (2017). Key challenges of using video when investigating social practices in education: contextualization, magnification, and representation. International fournal of Research \& Method in Education, 40(5), 511-523.

Bratberg, Ø. (2017). Tekstanalyse for samfunnsvitere (2.utgave). Oslo: Cappelen Damm Akademisk.

Breivega, K. R. \& Johansen, S. P. (2016). Frå sjanger til teksttype i skriveopplæringa. Norsklceraren, 40(2), 50-62.

Brok, L. S. (2014). Skrivedidaktik på mellemtrinnet. Viden om lcesning, 15, 10-19.

Bueie, A. A. (2016). Nyttige og mindre nyttige lærerkommentarer-slik elevene ser det. Nordic fournal of Literacy Research, 2(1).

Christensen, T. S., Elf, N. F. \& Krogh, E. (2014). Skrivekulturer $i$ folkeskolens niende klasse: Syddansk Universitetsforlag.

Dunn, K. C. \& Neumann, I. B. (2016). Undertaking Discourse Analysis for Social Research. Michigan: University of Michigan Press.

Eriksen, H. (2017). Vurdering for læring i norskfaget: Om lærerens skriftlige tilbakemeldinger på skriftlige tekster. Acta Didactica Norge, 11(1), 26, sider.

Evensen, L. S. (2010). En gyldig vurdering av elevers skrivekompetanse?. I J. Smidt, I. Folkvord \& A. J. Aasen (Red.), Rammer for skriving: om skriveutvikling $i$ skole og yrkesliv (s. 13-31). Trondheim: Tapir akademisk forlag.

Gabrielsen, I. L, Blikstad-Balas, M. \& Tengberg, M. (2017) Why and How do Students Read Fiction? A Study of The Role of Literary Texts in Lower Secondary Language Arts Lessons. Presentasjon på ECER-konferansen 2017 I København, for sammendrag se http://www.eera-ecer.de/ecer-programmes/conference/22/ contribution/42061/

Gee, J. P. (2004). Situated language and learning: a critique of traditional schooling. London: Routledge.

Gee, J. P. (2007). What video games have to teach us about learning and literacy. New York: Palgrave Macmillan.

Graham, S., Harris, K. R. \& Chambers, A. B. (2016). Evidence-based practice and writing instruction: a review of reviews. I C. A. MacArthur, S. Graham \& J. Fitzgerald (Red.), Handbook of writing research 2, 211-226. New York \& London: The Guilford Press.

Hitching, T. A., Nilsen, T. A. \& Veum, A. (2011). Diskursanalyse i praksis. Metode og analyse. Oslo: Cappelen Damm.

Helstad, K., \& Hertzberg, F. (2013). Faste mønstre som læringsstøtte i skriveundervisningen. Erfaringer fra et tverrfaglig utviklingsarbeid blant lærere i videregående skole. I D. Skjelbred \& A. Veum (Red.), Literacy $i$ leringskontekster. (s. 225-263).

Hertzberg, F. (2006). Å forstå en plan. Norsklcereren, 30(2), 2006.

Hertzberg, F. (2010). Arbeid med grunnleggende ferdigheter. I E. Ottesen \& J. Møller (Red.), Underveis, men $i$ svcert ulikt tempo.Et blikk inn $i$ ti skoler etter tre år med Kunnskapsløftet. Delrapport 3. Underveisanalyse av Kunnskapsløftet som styringsform (s. 77-89): NIFU STEP.

Hertzberg, F. \& Dysthe, O. (2012). Prosesskriving-hvor står vi i dag?. I: Synnøve Matre, Dagrun Kibsgaard Sjøhelle \& Randi Solheim (Red.): Teorier om tekst i møte med skolens lese-og skrivepraksiser. Oslo: Universitetsforlaget. (s. 59-71).

Hobel, P. (2015). Skriveordrer, tvcerfagligt samarbejde og demokratisk dannelse. I H. Otnes (Red.), A invitere elever til skriving. Ulike perspektiver på skriveoppgaver. (s. 119-138). Bergen: Fagbokforlaget.

Hobel, P. \& Piekut, A. (2016). Skrivedidaktiske udfordringer og perspektiver. I E. Krogh \& K. S. Jakobsen (Red.), Skriverudviklinger i gymnasiet. (s. 247-273). Odense: Syddansk Universitetsforlag.

Hull, G. \& Schultz, K. (2001). Literacy and learning out of school: A review of theory and research. Review of Educational Research, 71(4), 575-611.

Igland, M.-A. (2007). Svinaktig vanskelig. Skriftleg argumentasjon på ungdomssteget. I: Matre, Synnøve E̋ Hoel, Torlaug Løkensgard, Skrive for nåtid og framtid. Skriving $i$ arbeidsliv og skole. Trondheim: Tapir Akademisk Forlag. (s. 277-291).

Ivanič, R. (2004) Discourses of Writing and Learning to Write. Language and Education, 18(3), $220-245$.

Ivanič, R., Barton, D. \& Hamilton, M. (2000). Situated literacies: reading and writing in context. London: Routledge.

Jensen, L. V. (2016). Hvor ble det av sjangrene? Lareres undervisning i teksters form og funksjon på 8.trinn. Masteravhandling. Universitet i Oslo, Oslo.

Kiuhara, S. A., Graham, S., \& Hawken, L. S. (2009). Teaching writing to high school students: A national survey. Fournal of Educational Psychology, 101(1), 136.

Klette, K., Blikstad-Balas, M. \& Roe, A. (2017). Linking Instruction and Student Achievement. A research design for a new generation of classroom studies. Acta Didactica Norge, 11(3), 1-19. 


\section{Marte Blikstad-Balas}

Kringstad, T. \& Kvithyld, T. (2013). Fem prinsipper for god skriveopplæring. Bedre Skole (2), 71-79.

Krogh, E. \& Hobel, P. (2012). Årets bedste opgave: en analyse af en elevtekst i dens kontekst. I S. Matre, D. K. Sjøhelle \& R. Solheim (Red.), Teorier om tekst $i$ møte med skolens lese- og skrivepraksiser (s. 137-150). Oslo: Universitetsforlaget.

Kucirkova, N., Messer, D., Sheehy, K. \& Flewitt, R. (2013). Sharing personalised stories on iPads: a close look at one parent-child interaction. Literacy, 47(3), 115-122.

Kwok, M. N., Ganding III, E., Hull, G. A. \& Moje, E. B. (2016). Sociocultural Approaches to High School Writing Instruction. Examining the Roles of Context, Positionality, and Power. I C. A. MacArthur, S. Graham \& J. Fitzgerald (Red.), Handbook of writing research. 2, (s. 257-271). New York \& London: The Guilford Press.

Luke, A. (2012). Critical literacy: Foundational notes. Theory Into Practice, 51(1), 4-11.

MacGillivray, L. \& Curwen, M. S. (2007). Tagging as a social literacy practice. Fournal of Adolescent E Adult Literacy, 50(5), 354-369.

Maybin, J. (2007). Literacy under and over the desk: Oppositions and heterogeneity. Language and Education, 21(6), 515-530.

Myhill, D. (2017). "The inspiration myth: how professional writers manage the planning process". EARLI Conference, Tampere.

Olson, D. R. (2008). History of schools and writing. I C. Bazerman (Red.), Handbook of research on writing. History, society, school, individual, text (s. 283-292). New York \& London: Lawrence Erlbaum Associates.

Ottesen, E. \& Møller, J. (2010). Underveis, men i svcert ulikt tempo: et blikk inn i ti skoler etter tre år med Kunnskapsløftet. Delrapport 3 Underveisanalyse av Kunnskapsløftet som styringsform. Oslo: NIFU STEP.

Roe, A. \& Helstad, K. (2014). Den andre skriveopplæringen i Norge-om prosesskriving og skriving i og på tvers av fag. I R. Hvistendahl \& A. Roe (Red.), Alle tiders norskdidaktiker. (s. 171-194). Oslo: Novus. (s.171-194).

Skjelbred, D. \& Veum, A. (2013). Literacy i lceringskontekster. Oslo: Cappelen Damm Akademisk.

Smagorinsky, P. \& Mayer, R. E. (2014). Learning to be literate. I K. Sawyer (Red.), The Cambridge handbook of the learning sciences. (s. 605-625). Cambridge: Cambridge University Press.

Smidt, J. (2009). Ulike syn på skriving og skriveundervisning. I J. Smidt (Red.), Norskdidaktikk: ei grunnbok (s. 312-323). Oslo: Universitetsforlaget.

Slot, M. F. (2017). Læremidler, I Dolin, J. Ingerslev, G.H, Jørgensen, H.S (Red): Gymnasipædagogik kursiv. 3. utgave, (s. 410-429). Hans Reitzel Forlag.

Sørvik, G. O. \& Mork, S. M. (2015). Scientific literacy as social practice: Implications for reading and writing in science classrooms. Nordic Studies in Science Education, 11(3), 268-281.

Torrance, M. (2016). Understanding Planning in Text Production. I C. A. MacArthur, S. Graham \& J. Fitzgerald (Red.), Handbook of writing research (s. 72-87). New York \& London: The Guilford Press.

Vagle, W. \& Evensen, L. S. (2005). Oppgavesettene og elevenes oppgavevalg i KAL-årene. IK. L. Berge, L. S. Evensen, F. Hertzberg \& W. Vagle (Red.), Ungdommers skrivekompetanse. Bind 1. Norsksensuren som kvalitetsvurdering (s. 161-203). Oslo: Universitetsforlaget.

Veum, A. (2015). Skriveoppgåver i utvikling? Skrivediskursar i norskbøker for ungdomsskulen gjennom 30 år. I H. Otnes (Red.), Å invitere elever til skriving. Ulike perspektiver på skriveoppgaver (s. 83-100). Bergen: Fagbokforlaget.

Yi, Y. (2010). Adolescent multilingual writers' transitions across in-and out-of-school writing contexts. fournal of Second Language Writing, 19(1), 17-32.

Øgreid, A. K. (2016). Skriveramme som støtte i arbeidet med fagskriving? Studie av 8. klasse elevers tekstskaping i samfunnsfag. Acta Didactica Norge, 10(1), 19 sider. 